\title{
Bantuan Teknis Profesional Pengembangan Kurikulum Kepada Tim Pengembang Kurikulum Daerah Sebagai Wahana Pemberdayaan Staf Pusat Kurikulum
}

\author{
Sutjipto \\ E-mail: sutjipto.55@gmail.com
}

\begin{abstract}
Abstrak: Kajian yang dikemukakan ini dimaksudkan untuk memperoleh gambaran tentang pemberdayaan staf Pusat Kurikulum melalui strategi kegiatan bantuan teknis profesional pengembangan kurikulum di daerah. Metode kajian ini yaitu deskriptif, di mana data utama diolah berdasarkan program kegiatan, pelaksanaan kegiatan, dan laporan hasil kegiatan Pusat Kurikulum tahun 2006 s.d. tahun 2010 berkait dengan bantuan teknis profesional pengembangan kurikulum kepada TPK provinsi di 33 provinsi, dan TPK kabupaten/kota di 120 kabupaten/kota. Informasi dikumpulkan dengan menggunakan teknik dokumentasi, diskusi terfokus secara kelompok. Teknik analisis data yang dipergunakan, yaitu deskripsi, dan interpretasi. Hasil kajian menunjukkan bahwa peningkatan kemampuan profesional staf dalam pengembangan kurikulum merupakan usaha sadar dan berkesinambungan dari pimpinan Pusat Kurikulum. Pentingnya penciptaan suatu budaya kelembagaan dengan suasana atau iklim yang memungkinkan staf berkembang secara sehat dalam manajemen yang memperkuat potensi staf dan adanya jaminan perlindungan. Dengan demikian, potensi staf dapat dibangun secara positif dan kondusif yang pada gilirannya bisa memandirikan staf dalam berkarya. Kajian ini menunjukkan juga bahwa strategi pemberdayaan staf di tingkat Pusat Kurikulum sangat berpengaruh terhadap capaian keberhasilan kegiatan bantuan teknis profesional pengembangan kurikulum kepada TPK daerah.
\end{abstract}

Kata kunci: kemandirian, profesionalisme, kurikulum, dan bantuan teknis

\begin{abstract}
This study set out to get a view of empowerment Curriculum Center staff through a strategy of professional technical assistance activities in the area of curriculum development. Methods This study is descriptive, where the main data is processed based on program activities, implementation activities, and report the results of activities Curriculum Center between 2006 through 2010 related to the professional technical assistance to the TPK provincial curriculum development in 33 provinces, and TPK district in 120 districts/cities. Information was collected using documentary techniques, focus group discussions, and involved role in the activities. The data analysis technique used, namely description, and interpretation. The study shows that the increase in professional skills (professional development) staff in curriculum development is really a conscious and sustained effort from the leadership of Curriculum Centre. The importance of the creation of a cultural institution with the atmosphere or climate that allows staff to develop, a sound management in strengthening the potential or staff resources and the protection jaminnan staff so that potential can be constructed in a positive and conducive environment which in turn can memandirikan staff in making the work is also a prominent finding in this study. Furthermore, this study also shows that the strategy of empowering the staff at the Curriculum Center is very influential on the successful achievements of technical assistance activities of professional development curriculum to local corruption.
\end{abstract}

Key words: independence, professionalism, curriculum, and technical assistance 


\section{Pendahuluan}

Satu hal penting yang dikemukakan oleh Kepala Pusat Kurikulum dalam pertemuan akhir tahun 2006 adalah: "...bahwa jika Anda semua staf Pusat Kurikulum tidak senantiasa meningkatkan kinerjanya dalam menyikapi semua pekerjaan, maka lambat laun dan pasti lembaga kita akan kurang diperhitungkan oleh orang lain". Pernyataan tersebut jika dicermati secara mendalam mengandung makna yang amat dalam, yaitu bahwasannya staf perlu memiliki keragaman kompetensi yang handal, baik pada pengembangan karakter pribadi maupun konteks penelitian dan pengembangan, substansi mata pelajaran, dan metodologi pembelajaran yang secara terus-menerus harus selalu ditingkatkan. Diharapkan staf benar-benar memahami lingkup pekerjaannya, memiliki tingkat pengetahuan, keterampilan, dan sikap yang "mumpuni" dalam melaksanakan tugas pengembangan perangkat kurikulum.

Dalam suatu lembaga, aset sumber daya manusia merupakan aset yang sangat penting, di samping aset penganggaran, dan aset fisik (termasuk hasil karya) karena ke dua aspek tersebut dikendalikan oleh manusia. Artinya, keberhasilan suatu lembaga untuk mencapai tujuan-tujuan yang telah ditetapkan akan ditentukan oleh sistem pemberdayaan terhadap sumber daya manusia dalam lembaga itu. Kemampuan lembaga memberdayakan staf dalam rangka efektivitas lembaga secara langsung berhubungan dengan tingkat perhatian pimpinan terhadap nilai keberadaan staf dan nilai pemberdayaan staf. Pemberdayaan staf menjadi kata yang tepat mengingat kebutuhan yang sangat mendesak bagi peningkatan kualitas pendidikan, terutama untuk pencitraan publik. Pemberdayaan merupakan aset yang bersifat abstrak, unik, dan senantiasa berproses dengan dinamika yang tidak sama antara pemimpin yang satu dengan pemimpin yang lain.

Hasil karya dari suatu lembaga pada akhirnya akan menghasilkan citra di mata "pengguna", baik di lingkungan kementerian maupun dalam masyarakat luas. Karya yang monumental akan membangun citra lembaga menjadi eksis, dan hal ini akan memperkuat kepercayaan lembaga lain terhadap Pusat Kurikulum, di mana nama lembaga tersebut sekarang telah berubah menjadi Pusat Kurikulum dan Perbukuan-. Tingkat kepercayaan lembaga lain terhadap Pusat Kurikulum akan turut andil dalam menentukan keberlangsungan lembaga. Dengan pernyataan sebagaimana dikemukakan di atas, kepala pusat menyadari bahwa faktor manusia akan sangat menentukan maju mundurnya lembaga yang dipimpinnya. Lembaga yang memiliki sumber daya manusia yang berkualitas baik tentu akan berkembang dengan baik, sebaliknya, apabila kualitas manusianya rendah tentu lembaga itu akan mengalami kemunduran.

Bagi staf, masalah keberlangsungan suatu lembaga barangkali bukan menjadi masalah serius mengingat mereka umumya merupakan pegawai negeri sipil. Artinya, maju mundurnya suatu lembaga tidak akan berpengaruh secara signifikan terhadap posisi kepegawaiannya. Anggapan ini tentunya amat menyesatkan mengingat bahwa keberlangsungan suatu lembaga akan berdampak secara langsung maupun tidak langsung pada seluruh karyawan. Dampak langsung misalnya yaitu hasil karya dari lembaga itu tidak akan dipakai oleh orang lain, tidak dianggap penting oleh pihak lain. Jika hal ini terjadi, maka secara moral seluruh karya-wan akan menanggung dampaknya. Sedangkan secara tidak langsung, misalnya penurunan jumlah anggaran yang diperoleh, dan hal ini akan mengakibatkan penurunan pula jumlah kegiatan yang pada gilirannya akan mengurangi pendapatan staf. Oleh karena itu, ke depan Pusat Kurikulum, memiliki tantangan yang besar dalam pengelolaan lembaganya.

Pemberdayaan staf diyakini akan menentukan hasil kerja staf, dan pada akhirnya akan menentukan berkembangnya potensi staf ke arah profesionalitas. Staf yang profesional menurut Schein dalam Trianto dan Tuti (2006) salah satunya yaitu harus selalu berorientasi pada usaha memberikan karya nyata sebagai ahli serta dituntut untuk dapat mengevaluasi unjuk kerjanya sebagai refleksi bagi upaya peningkatan diri (self development oriented).

Masalah kinerja staf yang secara faktual terjadi hampir pada semua bidang dan bagian (saat itu di Pusat Kurikulum terdapat tiga bidang dan satu bagian tata usaha) menunjukkan gejala 
yang tidak merata tingkat profesionalitasnya. Hasil diskusi yang penulis lakukan dengan pimpinan Pusat Kurikulum (dalam hal ini kepada tiga kepala bidang) sekitar bulan Oktober tahun 2005 menunjukkan adanya kekhawatiran bagi sebagian staf manakala mereka harus melakukan bantuan teknis profesional pengembangan kurikulum kepada konsumen. Selebritas memfasilitasi teknis pengembangan kurikulum masih belum menjiwai setiap staf.

Di samping itu, berbagai fungsi dasar keberadaan staf Pusat Kurikulum, seperti memberi layanan pendampingan pengembangan kurikulum, hanya dirasakan positif tidak lebih dari seperempat dari jumlah staf. Mayoritas, tidak kurang dari tiga perempat dari jumlah staf, umumnya belum pernah melakukan kegiatan pendampingan secara langsung pengembangan kurikulum. Artinya, program lembaga dalam meningkatkan kapasitas staf melalui kegiatan bantuan teknis profesional pengembangan kurikulum, memberikan penataran tentang penyusunan kurikulum, ataupun mensosialisasikan kebijakan baru berkait kurikulum lebih banyak dinilai kurang. Pertanyaan yang muncul bagi pimpinan lembaga yaitu bagaimana menumbuhkan semangat profesionalitas di tengah gempuran kebijakan otonomi daerah dan otonomi pendidikan yang ditandai dengan kewenangan untuk mengembangkan kurikulum sendiri, terutama di tingkat satuan pendidikan?.

Menyikapi hal tersebut, Pusat Kurikulum, ada beberapa hal yang dilakukan. Pertama, perlunya menggiatkan kembali peningkatan kapasitas staf terhadap makna dasar pengorganisasian kontinuitas dan eksistensi suatu kurikulum, yaitu mencakup konsep: 1) curriculum construction, lazimnya disebut pembuatan atau pengembangan atau penyusunan kurikulum, yaitu serangkaian aktivitas untuk menyusun sebuah dokumen kurikulum satuan pendidikan yang didasarkan pada suatu kebijakan pemerintah; 2) curriculum implementation, yaitu serangkaian aktivitas untuk melaksanakan suatu kurikulum dalam berbagai bentuk kegiatan kurikuler. Kegiatan kurikuler dapat dilaksanakan melalui pembelajaran tatap muka, tugas terstruktur, dan tugas mandiri. Pada tahap pelaksanakan inilah sering kali ditemukan adanya kelemahan- kelemahan suatu kurikulum yang dapat diamati karena pelaksanaan kurikulum akan bersinggungan dengan banyak faktor; dan 3) yaitu serangkaian aktivitas untuk mengkaji kekuatan, kelemahan, dan dampak dari suatu kurikulum.

Kedua, sejumlah upaya dilakukan oleh Pusat Kurikulum dalam rangka mengembangkan kapasitas staf, misalnya setiap orang harus menjadi penanggung jawab suatu kegiatan secara mandiri sehingga mereka terlatih untuk mampu menggali, mengembangkan, menganalisis, dan menggunakan informasi untuk kepentingan pekerjaan profesionalnya. Upaya itu, misalnya menjadi penanggung jawab pengembangan kurikulum satuan pendidikan di daerah perbatasan antarnegara, menjadi koordinator teknis maupun substansi kegiatan bantuan teknis tim pengembang kurikulum provinsi melalui jaringan kurikulum, atau menjadi koordinator pengembang bahan ajar untuk satuan pendidikan tertentu. Bahkan, Belfiore (1996) dalam bukunya "Understanding Curriculum Development in the Workplace" (di situs puskur.net/index) menjelaskan bahwa pengembang kurikulum harus juga memiliki inisiatif yang kuat untuk memahami konteks kurikulum yang lebih luas.

Mengacu pada permasalahan yang dikemukakan di atas, kajian ini dimaksudkan untuk memperoleh gambaran tentang pemberdayaan staf Pusat Kurikulum melalui strategi kegiatan bantuan teknis profesional pengembangan kurikulum di daerah.

\section{Kajian Teori \\ Bantuan Teknis Profesional Pengembangan Kurikulum}

Sejak dikeluarkannya kebijakan mengenai Standar Nasional Pendidikan sebagai perangkat turunan dari Undang-Undang Nomor 20 Tahun 2003 tentang Sistem Pendidikan Nasional maka peran Pusat Kurikulum yang sejak lahirnya bertugas mengembangkan kurikulum nasional harus menyesuaikan diri dengan kebiasaan dan budaya konfigurasi pengembangan kurikulum yang tidak lagi secara nasional. Dengan melakukan berbagai analisis dan kajian terhadap fungsi dan tugas serta berbagai peraturan serta kondisi empiris yang ada. Pusat Kurikulum berpendapat bahwa salah satu fungsi dan tugas 
Pusat Kurikulum ke depan dapat dialihkan dari pengembang kurikulum nasional menjadi memberikan bantuan teknis profesional pengembangan kurikulum. Cakupan kegiatan tersebut dapat berupa advokasi dan pendampingan kepada TPK di daerah dalam rangka pencerahan konsep serta workshop pengembangan kurikulum, dan pengembangan model-model kurikulum yang dapat diadaptasi maupun diadopsi oleh satuan pendidikan jika mereka belum mampu menyusun kurikulum sendiri.

Sehubungan dengan perubahan fungsi, tugas, kebiasaan dan budaya orientasi serta kondisi lembaga saat itu maka lokus kegiatan Pusat Kurikulum sejak tahun 2006 hingga saat ini (2011) antara lain melakukan kegiatan bantuan teknis profesional pengembangan kurikulum kepada TPK kabupaten/kota maupun TPK provinsi. Untuk tingkat kabupaten/kota tujuan dari kegiatan ini adalah membentuk TPK daerah agar dapat meningkatkan kemampuan profe-sionalnya dalam mendampingi satuan pendidikan atau kelompok satuan pendidikan di daerahnya dalam pengembangan kurikulum tingkat satuan pendidikan. Sedangkan untuk tingkat provinsi tujuan dari kegiatan ini adalah memberdayakan dan memantapkan secara terus menerus TPK provinsi agar dapat meningkatkan kemampuan profesionalnya dalam membina dan mendampingi TPK kabupaten/kota, satuan pendidikan atau kelompok satuan pendidikan di wilayahnya dalam pengembangan kurikulum.

Bantuan teknis profesional pengembangan kurikulum kepada TPK daerah merupakan salah satu hasil dari analisis, kajian dan upaya memaknai perubahan kebijakan yang terjadi yang melanda Pusat Kurikulum. Di mana salah satu pertimbangannya ialah bahwa banyaknya satuan pendidikan yang tersebar di seluruh Indonesia tidak memungkinkan Pusat Kurikulum membantu satu persatu satuan pendidikan dalam penyusunan kurikulum. Harus ada strategi baru agar satuan pendidikan mampu menyusun kurikulumnya masing-masing, yaitu pembentukan TPK di daerah. Oleh karena itu, maka sejak tahun 2006 seluruh staf Pusat Kurikulum mempunyai tugas institusional baru, yaitu memberikan bantuan teknis profesional pengembangan kurikulum baik terhadap TPK daerah maupun terhadap satuan pendidikan mulai dari tingkat pendidikan anak usia dini sampai dengan jenjang pendidikan dasar dan menengah. Tugas yang baru ini bagi staf Pusat Kurikulum tentunya bukan pekerjaan yang mudah karena sifat dari pekerjaan itu memerlukan persyaratan kemampuan yang prima dari berbagai aspek secara teknis, baik manajerial maupun profesional.

Dengan tugas baru yang diembannya staf Pusat Kurikulum harus senantiasa mengembangkan kemampuan profesionalnya setiap saat secara dinamis dan terus menerus agar mampu memfasilitasi bantuan teknis sesuai yang diharapkan. Bantuan teknis profesional kurikulum dimaknai sebagai suatu upaya untuk memberikan keahlian kepada orang-orang yang secara khusus dipersiapkan untuk melakukan pengembangan kurikulum. Dalam konteks ini, maka para pemberi bantuan teknis profesional pengembangan kurikulum mutlak harus terlebih dahulu sudah memiliki keahlian maupun pengalaman dalam bidang pengembangan kurikulum.

Sementara itu, istilah profesional berasal dari kata sifat, yaitu profession (pekerjaan) yang berarti sangat mampu melakukan pekerjaan. Dalam Kamus Besar Bahasa Indonesia (Pusat Bahasa, 2001) profesional diartikan sebagai "sesuatu yang memerlukan kepandaian khusus untuk menjalankannya". Dengan kata lain, profesional, yaitu serangkaian keahlian yang dipersyaratkan untuk melakukan suatu pekerjaan yang dilakukan secara efesien dan efektif dengan tingkat keahlian yang tinggi dalam rangka untuk mencapai tujuan pekerjaan yang maksimal. Sementara itu, dalam kamus "Theadvanced Learner's Dictionary of Current English, yang ditulis A.S. Hornby, dkk (1973) dinyatakan bahwa "profession is accuption, esp. one requiring advanced educational and special training". Artinya, profesional adalah jabatan yang memerlukan suatu pendidikan tinggi dan latihan secara khusus. Suatu jabatan akan menentukan aktivitasaktivitas sebagai pelaksana tugas. Hal ini berarti bukan jabatannya yang menjabat predikat profesional, tetapi keahliannya dalam melaksanakan pekerjaan.

Menurut Abeng (1997), istilah profesional memiliki aspek-aspek tertentu. Aspek yang dimaksud ialah menyangkut masalah ilmu penge- 
tahuan (knowledge), aspek keterampilan (skill), serta sikap mental (attitude). Lebih lanjut, Abeng mengemukakan bahwa aspek pengetahuan, keterampilan dan sikap mental setara dan sama petingnya sebagai fondasi untuk mem-bangun kualitas dan mutu profesional. Ilmu pengetahuan diperoleh dari hasil pendidikan, oleh sementara ahli disyaratkan sampai pada advanced educational, sedang skill atau keterampilan didapat dari latihan, dan aktivitas melaksanakan pekerjaan atau learned on the job. Adapun attitude atau sikap mental merupakan kepribadian, tetapi bisa dididik lewat pendidikan agama dan pendidikan moral sejak dini, di samping tuntutan yang berasal dari lingkungannya.

Berdasarkan tiga pengertian di atas dapat dipahami bahwa seseorang dikatakan profesional karena ia mempunyai standar kualitas dan ciri-ciri tertentu. Seorang profesional merupakan hasil dari sesuatu yang dipersiapkan dan dibina di pekerjaannya. Profesi tersebut terus berkembang sejalan dengan perkembangan ilmu pengetahuan dan teknologi, maka seorang profesional adalah seorang yang secara berkembang atau trainable. Trainable dari seorang profesional tentunya akan lebih mudah apabila mereka mempunyai dasardasar ilmu pengetahuan yang kuat dalam pengembangan kurikulum sehingga akan mempermudah dalam melakukan bantuan teknis profesional pengembangan kurikulum di daerah.

\section{Pemberdayaan}

Pemberdayaan merupakan bagian dari pekerjaan sehari-hari dari manajemen, yang pada kenyataannya tidak mudah untuk diterapkan. Apabila tidak tepat, kemungkinan malah bisa berakibat buruk pada kinerja suatu lembaga. Oleh karena itu, yang perlu diketahui yakni yang melatarbelakangi pemberdayaan seseorang, bagaimana prosesnya, serta segala sesuatu yang berhubungan dengan pemberdayaan seseorang itu sendiri. Namun, satu hal yang pasti bahwa pemberdayaan merupakan unsur penting yang memengaruhi efektivitas suatu lembaga. Bagaimana suatu lembaga memberdayakan stafnya sehingga mereka mengeluarkan seluruh potensi yang dimilikinya untuk mencapai tujuan lembaga merupakan tugas pemimpin dalam mengelola lembaga. Sebuah lembaga yang efektif dalam mencapai tujuan tidak terlepas dari efektivitas masing-masing individu di dalamnya. Dengan pengelolaan sumber daya staf yang profesional akan dapat diwujudkan pemberdayaan manusia sebagai sumber daya untuk mewujudkan lembaga yang efektif.

Pemberdayaan dilahirkan dari bahasa Inggris, yakni empowerment, yang mempunyai makna dasar 'pemberdayaan', di mana 'daya' bermakna kekuatan (power). Bryant \& White (1987) dalam http://www.pemberdayaan.com/pemberdayaan/ konsep-pemberdayaan-membantu-masyarakatagar-bisa-menolong-diri-sendiri.html menyatakan bahwa pemberdayaan sebagai upaya menumbuhkan kekuasaan dan wewenang yang lebih besar kepada staf dengan cara menciptakan mekanisme dari dalam (build-in) untuk meluruskan keputusankeputusan alokasi yang adil, yakni dengan menjadikan mereka mempunyai pengaruh. Hal ini dapat dimaknai bahwa pemberdayaan bukan sekadar memberikan kesempatan kepada staf menggunakan sumber daya dan biaya kegiatan saja, tetapi juga upaya untuk mendorong mencari cara menciptakan kebebasan dari struktur yang opresif.

Dalam pandangan Pearse dan Stiefel dalam Prijono dan Pranarka (1996) pemberdayaan mengandung dua kecenderungan, yakni primer dan sekunder. Kecenderungan primer berarti proses pemberdayaan menekankan proses memberikan atau mengalihkan sebagian kekuasaan, kekuatan atau kemampuan kepada seseorang agar individu menjadi lebih berdaya. Sedangkan kecenderungan sekunder melihat pemberdayaan sebagai proses menstimulasi, mendorong atau memotivasi individu agar mempunyai kemampuan atau keberdayaan untuk menentukan apa yang menjadi pilihannya.

Pemberdayaan menurut Hikmat (2001: 162163) pada hakikatnya merupakan kegiatan staf diarahkan kepada upaya untuk mendorong dan memobilisasi sumber-sumber sosial sehingga staf dapat menyatakan kebutuhan-kebutuhannya, menyampaikan pendapat-pendapatnya dan dapat menggali serta memanfaatkan sumbersumber lokal yang tersedia. Dengan demikian staf dapat terlibat aktif dalam penanganan masalah mulai dari identifikasi masalah sampai dengan menikmati hasilnya. Pengertian staf mengacu kepada sekelompok orang yang belajar hidup dan bekerja bersama dalam suatu organisasi, dalam 
hal tulisan ini staf adalah jajaran pembantu pimpinan di Pusat Kurikulum yang lazim disebut staf teknis. Dari sudut pandangan sistem, staf merupakan suatu "holon" (suatu konsep yang menyatakan bahwa sistem dapat dipandang sebagai unit yang berdiri sendiri, tetapi juga sekaligus dapat dipandang sebagai bagian dari sistem yang lebih besar atau sebagai subsistem).

Menurut Simon (1990:23), pemberdayaan adalah suatu aktivitas refleksif, suatu proses yang mampu diinisiasikan dan dipertahankan hanya oleh agen atau subjek yang mencari kekuatan atau penentuan diri sendiri (self-determination). Sementara proses lainnya hanya dengan memberikan iklim, hubungan, sumber-sumber dan alat-alat prosedural yang melaluinya agar staf dapat meningkatkan kehidupannya. Pemberdayaan merupakan sistem yang berinteraksi dengan lingkungan sosial dan fisik, bukan merupakan upaya pemaksaan kehendak, proses yang dipaksakan, kegiatan untuk kepentingan pemrakarsa dari luar, keterlibatan dalam kegiatan tertentu saja, dan makna-makna lain yang tidak sesuai dengan pendelegasian kekuasaan atau kekuatan sesuai potensi yang dimiliki staf.

Berkait dengan potensi, Adimihardja dan Hikmat (2000:14-15) berpendapat bahwa staf sebenarnya memiliki banyak potensi baik dilihat dari sumber-sumber daya batiniyah maupun dari sumber-sumber sosial dan budayanya. Staf memiliki "kekuatan" yang bila digali dan disalurkan akan menjadi energi yang besar untuk peningkatan kinerja tempat kerjanya. Cara menggali dan mendayagunakan sumber-sumber daya yang ada dalam diri staf inilah yang menjadi inti dari pemberdayaan staf.

Ahli Iain, McArdle (1989) menyatakan bahwa pemberdayaan diartikan sebagai proses pengambilan keputusan oleh orang-orang yang secara konsekuen melaksanakan keputusan tersebut. Orang-orang yang telah mencapai tujuan kolektif melalui kemandiriannya termasuk diberdayakan, bahkan mungkin lebih diberdayakan melalui usaha mereka sendiri dan akumulasi pengetahuan, keterampilan serta sumber-sumber lainnya, dalam rangka mencapai tujuan mereka sendiri tanpa tergantung pertolongan dari hubungan eksternal. Lebih lanjut McArdle juga mengemukakan bahwa pemberdayaan utamanya bukan untuk mencapai suatu tujuan semata, melainkan pentingnya proses kemitraan dan partisipasi dalam pengambilan keputusan.

Dalam pemberdayaan menurut Craig and Mayo (1995) aspek partisipasi merupakan komponen penting di dalam kemandirian dan proses pemberdayaan. Oleh karena itu, sebaiknya seorang staf hendaknya senantiasa terlibat dalam proses organisasi tersebut sehingga mereka lebih memperhatikan hidupnya, untuk memperoleh rasa percaya diri, serta memiliki rasa harga diri dan pengetahuan untuk mengembangkan keahlian baru. Prosesnya secara kumulatif, semakin banyak keterampilan yang dimiliki seorang staf, semakin bisa seseorang itu untuk mampu berpartisipasi, juga akan semakin banyak yang diperolehnya.

Pemberdayaan pada intinya memberikan tekanan pada otonomi pengambilan keputusan. Adapun inti dari pemberdayaan menurut Winarni dalam Sulistiyani (2004:79) ada tiga hal, yakni: (1) memungkinkan adanya pengembangan (enabling), (2) memperkuat potensi atau daya (empowering), dan (3) terciptanya kemandirian. Hal ini dapat diartikan bahwa pemberdayaan staf merupakan penciptaan suasana atau iklim kerja yang memungkinkan potensi staf dapat berkembang. Setiap staf pasti memiliki daya, akan tetapi staf belum menyadari, atau bahkan belum diketahui. Oleh karena itu, daya harus digali, dan kemudian dikembangkan agar menjadi mandiri.

Dari delapan pandangan di atas dapat disarikan bahwa pemberdayaan staf tidak hanya mengembangkan potensi kompetensi staf, tetapi juga harkat dan martabat, rasa percaya diri dan harga dirinya, dan terpeliharanya tatanan nilai sosial budaya lembaga. Pemberdayaan sebagai konsep sosial budaya yang implementatif dalam bekerja yang berpusat pada staf, tidak saja menumbuhkan dan mengembangkan nilai kinerja, tetapi juga nilai tambah sosial dan nilai tambah budaya. Di sisi lain, pemberdayaan berdasarkan perspektif ilmu-ilmu sosial merupakan proses menampilkan peran-peran aktif dan kolaboratif antara staf dan mitranya. Hal ini secara paradoks juga memberdayakan sistem lain, atau secara paternalistik melimpahkan kekuatan (power) kepada orang lain yang juga berarti memberdayakan mereka. 
Dengan berlandaskan dari dua kajian teori yang diurai di atas bahwa bantuan teknis profesional pengembangan kurikulum kepada TPK daerah sebagai wahana pemberdayaan staf, maka dalam kajian ini penulis merujuk pendapat yang dikemukakan oleh Abeng (1997) bahwa staf Pusat Kurikulum haruslah memiliki ilmu pengetahuan (knowledge), keterampilan (skill), dan sikap mental (attitude) yang kuat dalam hal pengembangan kurikulum sehingga staf memiliki standar kualitas dan ciri-ciri tertentu yang dipersiapkan dan dibina dalam melaksanakan pekerjaannya. Di mana ketiga domain tersebut bisa didapat dari pendidikan dan latihan, serta aktivitas melaksanakan pekerjaan di lembaganya atau learned on the job. Adapun attitude atau sikap mental merupakan kepribadian yang bisa dididik lewat pendidikan agama (seluruh staf memeluk agama secara baik) dan pendidikan moral.

Pemberdayaan dalam kajian ini adalah dalam rangka learned on the job agar staf menjadi lebih mandiri dalam melaksanakan bantuan teknis profesional pengembangan kurikulum. Untuk itu, maka setiap tahun di Pusat Kurikulum selalu diupayakan adanya program pendidikan dan pelatihan guna membangun daya staf, dengan cara mendorong, memotivasi, dan membangkitkan kesadaran akan potensi yang dimiliki staf serta berupaya untuk mengembangkannya dengan dilandasi proses kemandirian. Strategi pemberdayaan staf yang ditempuh pimpinan Pusat Kurikulum menurut pandangan penulis diadopsi dari pendapat yang dikemukakan oleh Winarni dengan penambahan aspek protecting, yaitu: 1) memungkinkan adanya pengembangan (enabling) maksudnya menciptakan suasana atau iklim yang memungkinkan potensi staf untuk berkembang, 2) memperkuat potensi atau daya (empowering) menerapkan langkah-langkah nyata, yakni melaksanakan bantuan teknis profesional pengembangan kurikulum dengan menampung berbagai masukan dan pemfasilitasan yang diperlukan, 3) perlindungan (protecting) dimaksudkan melindungi dan membela kepentingan staf, dan 4) terciptanya kemandirian staf dalam kegiatan bantuan teknis profesional pengembangan kurikulum. Karenanya, empat aspek inilah yang akan dikaji secara mendalam dalam tulisan ini.

\section{Metodologi Kajian}

Metode kajian ini yaitu deskriptif, di mana data utama diolah berdasarkan program kegiatan, pelaksanaan kegiatan, dan laporan hasil kegiatan Pusat Kurikulum antara tahun 2006 sampai dengan tahun 2010 berkait dengan bantuan teknis profesional pengembangan kurikulum kepada TPK provinsi di 33 provinsi, dan TPK kabupaten/kota di 120 kabupaten/kota yang dilakukan oleh staf Pusat Kurikulum. Artinya, kajian ini secara konseptual mendeskripsikan fakta/ kejadian yang terjadi pada saat itu (Sax, 1979:1718; Nana Sudjana \& Ibrahim 1989: 64)

Pengkajian secara deskriptif juga merujuk pendapat Crowl (1996), menurutnya, deskriptif adalah menggambarkan dengan tujuan untuk dapat menerangkan dan memprediksi terhadap suatu gejala yang berlaku atas dasar data yang diperoleh di lapangan. Artinya, kajian ini dimaksudkan untuk mendeskripsikan secara sistematis, dan faktual mengenai fakta-fakta dan sifat secara apa adanya. Informasi dikumpulkan dengan menggunakan teknik dokumentasi (laporan hasilhasil kegiatan), fokus grup diskusi, dan terlibat peran dalam kegiatan.

Populasinya, yaitu staf Pusat Kurikulum. Sampel diambil secara purposif yang merupakan staf teknis yang berperan sebagai pelaku utama dalam kegiatan bantuan teknis profesional pengembangan kurikulum kepada TPK provinsi, dan TPK kabupaten/kota.

Prosedur kajian ini berupa menganalisis hasil, pembahasan, generalisasi, dan memberikan penafsiran.

Teknik analisis data yang dipergunakan dalam kajian ini merujuk pendapatnya Fairclough (1997), yaitu deskripsi, dan interpretasi. Pada deskripsi hasil analisis informasi diuraikan tanpa menghubungkan dengan aspek lain. Pada interpretasi, ditafsirkan hasil analisis informasi pada tahap deskripsi sekaligus dicari penjelasannya.

\section{Pembahasan Hasil Kajian}

\section{Mengapa perlu suasana atau iklim yang memungkinkan staf berkembang (enabling)}

Pengembangan kurikulum yang disesuaikan dengan kebutuhan, potensi, dan kondisi daerah maupun satuan pendidikan merupakan kebijakan nasional memerlukan penerjemahan dari pihak 
satuan pendidikan maupun daerah tentang mau ke mana pendidikan di institusinya maupun di daerahnya. Dalam kaitan ini, disadari bahwa pemerintah pusat tidak memiliki kemampuan untuk menerjemahkan hal tersebut sehubungan dengan kompleksitas dan variasi masing-masing daerah dan satuan pendidikan. Kemampuan untuk menerjemahkan kebutuhan, potensi, kondisi daerah, dan satuan pendidikan sehingga menjadi kurikulum khas mereka harus dijawab dengan mengembangkan sumber daya/potensi daerah. Pengembangan sumber daya yang merupakan kesiapan daerah dalam mengembangkan dan mengelola kurikulum, diperlukan adanya wadah bagi peningkatan kemampuan tersebut yang secara sistemik harus diwujudkan dengan cara membentuk TPK daerah. Tim ini bukan hanya dituntut mampu melakukan penyusunan kurikulum satuan pendidikan semata, melainkan yang lebih penting lagi yakni mampu melakukan pengembangan kurikulum secara terus menerus sesuai siklus pengembangan kurikulum, yaitu penyusunan, pelaksanaan, dan evaluasi. Refleksi tersebut mengemuka dalam rapat tahunan pimpinan Pusat Kurikulum beserta staf pada akhir tahun 2006.

Upaya pembentukan TPK daerah oleh Pusat Kurikulum dilakukan melalui bantuan teknis profesional pengembangan kurikulum, baik di tingkat provinsi maupun di tingkat kabupaten/ kota. Di tingkat provinsi diharapkan adanya TPK yang memiliki kemampuan untuk melakukan pengembangan kurikulum sehingga mampu memberikan bantuan teknis pengembangan kurikulum kepada TPK kabupaten/kota. Bantuan teknis di tingkat provinsi dikonsentrasikan pada usaha pengembangan kurikulum secara luas sampai dengan kemampuan tim untuk melakukan evaluasi dan monitoring pelaksanaan kurikulum di masing-masing daerah. Adapun bantuan teknis TPK kabupaten/kota di samping pengembangan kurikulum juga dikonsentrasikan pada kemampuan tim untuk melakukan pendampingan pengembangan kurikulum di tingkat satuan pendidikan serta kemampuan tim untuk melakukan evaluasi dan monitoring pelaksanaan kurikulum.

Hasil analisis terhadap program kerja Pusat Kurikulum dari tahun ke tahun menunjukkan bahwa materi kegiatan bantuan teknis profesional pengembangan kurikulum melibatkan beberapa aspek penyusunan kurikulum, pelaksanaan kurikulum dan evaluasi kurikulum yang secara simultan menjangkau secara luas atas beberapa hal yakni: 1) menyiapkan tim pengembang kurikulum daerah yang sejajar; 2) mengembangkan pengetahuan dan kompetensi berbagai pengembangan kurikulum; 3) memberikan nilai pengembangan kurikulum; 4) mengenalkan budaya pengembangan kurikulum; dan 5) membantu tim pengembang kurikulum daerah mengembangkan perspektif multi pengembangan.

Dalam ranah khusus menunjukkan bahwa konsep bantuan teknis profesional pengembangan kurikulum kepada TPK daerah menjadi konsep dasar pengembangan kurikulum di Indonesia saat ini. Sebagai hasil kajian, jawaban yang integral dapat menjembatani lahirnya model layanan pengembangan kurikulum ke dalam pendidikan dan pelatihan model profesional penyusunan kurikulum tingkat satuan pendidikan ke depan. Model ini dapat digunakan dalam sosialisasi, workshop, dan pendampingan penyusunan kurikulum guna menghasilkan profesionalisme pengembang kurikulum yang berkualitas, memiliki kompetensi, memiliki kesanggupan untuk mempertanggungjawabkan baik di depan komunitas tertentu, misalnya musyawarah guru mata pelajaran (MGMP), kelompok kerja guru (KKG) maupun di lingkup pengembang kurikulum kabupaten/kota itu sendiri.

Model bantuan teknis profesional pengembangan kurikulum kepada TPK daerah yang dikembangkan sebagai wahana pengemban otonomi staf, di dalamnya memiliki indikator keberhasilan yang dapat menjadi arah kompeten maupun tidak kompetennya seorang staf di Pusat Kurikulum. Dalam amatan terlibat, penciptaan kegiatan bantuan teknis profesional pengembangan kurikulum kepada TPK daerah menunjukkan bahwa pengerahan seperangkat keahlian dalam gaya, teknik, dan metodologi digunakan oleh staf sebagai ragam pendekatan keahlian yang diterapkan. Di samping itu, kemitraan, kerja sama sesama antaranggota tim maupun dengaan stakeholders terkait dan aktivitas konkret merupakan pengalaman yang amat berharga. Konsep bantuan teknis profesional pengembangan kurikulum yang diusung dari pusat tersebut 
ternyata banyak dibekali dengan ide yang dibalut kerja kreatif, jadwal terprogram, serta proses penuangan yang dilandasi oleh profesionalisme sehingga pengalaman staf ke depan menjadi semakin terasah dan berkembang.

Penekanan pada kerja mandiri dan tindak kreatif yang terstruktur menjadi kemampuan profesional menjadi semakin bertumpu pada landasan kebijakan yang kuat dan memadai. Hal itu antara lain yang disintesiskan dari amatan penulis dari kegiatan terlibat. Dengan demikian, proses ke depan terjadi simulasi yang mengerucut dan mampu menjadikan seorang staf yang mempelajari dengan konsep profesional dapat menciptakan budaya kerja bantuan teknis profesional pengembangan kurikulum secara jelas. Dalam hal ini dibutuhkan oleh Pusat Kurikulum penempaan yang memiliki landasan basis profesional sehingga diharapkan memenuhi kebutuhan seorang staf yang profesional menjadi tangguh dalam melaksanakan kegiatannya serta potensial dalam menghadapi tantangan di masa depan. Wahana konsep ini ditemukan bahwa nampaknya digunakan oleh pimpinan Pusat Kurikulum untuk menempa bibit-bibit profesional staf menjurus ke jalur yang sudah diatur atas ketentuan-ketentuan yang kadang tidak dapat ditawar lagi.

Beberapa indikator keprofesionalan staf yang berkembang yang ditemukan dalam amatan terlibat pada bentuk kegiatan bantuan teknis profesional pengembangan kurikulum kepada TPK daerah antara lain ialah: 1) menekankan pada proses dan produk/hasil kurikulum yang sesuai dengan karakteristik yang disesuaikan dengan kebutuhan, kondisi dan kekhasannya, yang dalam hal ini dikenal dengan istilah kurikulum tingkat satuan pendidikan (KTSP); 2) predikat profesionalisme menjadi model yang dicita-citakan Pusat Kurikulum; 3 ) obyektivitas, pendidikan dan pelatihan menjadi pengalaman batin yang terasah, sehingga setiap tahun di Pusat Kurikulum selalu ada satu jenis kegiatan berupa peningkatan kemampuan staf; 4) gaya penyampaian materi dan teknik profesional staf dalam melaksanakan bantuan teknis professional pengembangan kurikulum kepada TPK menjadi simbol konsep profesional,;5) prosedur pengembangan, strategi pelatihan, demonstrasi hasil workshop, dan unjuk kreativitas merupakan simbol profesionalismenya; 6) kemampuan, kemahiran, dan penampilan diri staf di hadapan TPK menjadi watak dan karakteristik konsep profesional mampu berkembang mandiri, dan berkelompok koloni; 7) karakteristik berproses dalam kegiatan bantuan teknis profesional pengembangan kurikulum yang berkualitas merupakan simbol pematangan diri staf dan penempaan mentalita pengalaman yang terasah dalam performa profesionalisme yang diidamkan; dan 8) profesionalisme yang dibina meliputi pelaku profesional staf dalam pemberdayaan.

Konsep pemberdayaan yang bertujuan agar staf di kemudian hari mampu memahami dan menjalani kehidupan institusi pengembangan kurikulum secara mendalam, dapat bekerja secara bermakna, dan dapat turut memuliakan kehidupan institusi nampak makin meningkat. Untuk itu, pimpinan Pusat Kurikulum senantiasa mengupayakan lewat program-program pendidikan dan pelatihan baik dalam negeri maupun luar negri agar staf harus senantiasa menguasai sejumlah pengetahuan dan kompetensi yang penting dalam bantuan teknis profesional pengembangan kurikulum, dan memahami nilai-nilai budaya baru institusinya serta makin percaya diri dalam bidang pengembangan kurikulum. Oleh karena itu, setiap tahun Pusat Kurikulum paling tidak ada dua program yang digulirkan. Pertama, diadakan pendidikan dan pelatihan peningkatan kemampuan staf dalam dinamika pengembangan kurikulum. Kedua, penugasan staf secara mandiri untuk bertanggung jawab secara penuh terhadap satu jenis kegiatan dengan strategi pemberdayaan.

Dengan kebijakan seperti itu, nampak bahwa staf pada akhirnya secara hakiki benar-benar mendapatkan makna bekerja di Pusat Kurikulum karena mereka merasakan betul apa yang diperlukan oleh instansinya. Pada sisi yang lain, ditemukan pula fakta bahwa staf merasa makin nyaman bekerja di Pusat Kurikulum. Nyaman, karena: 1) saat diberdayakan dilandasi oleh suatu kebijakan umum yang merumuskan tujuan yang ingin dicapai sebagai suatu kesatuan yang utuh; 2) didasari oleh seperangkat spesifikasi tujuan yang lengkap, menyeluruh, dan terpadu; dan 3) dipertimbangkan faktor-faktor determinan yang dianggap mempengaruhi dalam penentuan arah pengembangan bantuan teknis profesional 
pengembangan kurikulum, seperti kebijakankebijakan pusat dan daerah yang mengikat atau harus diacu, kondisi dinamika daerah, dan lainlain.

Dalam kerangka bantuan teknis profesional pengembangan kurikulum ditemukan fakta empiris bahwa strategi pemberdayaan dapat memunculkan rasa cinta ke dalam diri staf untuk manjadi manusia pembelajar itu. Bahkan, dalam pertemuan rutin bulanan staf mengemuka, menurut mereka, strategi seperti itu harus dan perlu. Dengan sendirinya maka kecintaan staf terhadap kebijakan pemberdayaan itu sendiri menjadi makin meningkat. Meminjam istilah Mochtar Buchori (Kompas, Senin 21 Maret 2011) kita harus mengembangkan love for learning dalam diri kita masing-masing demi pengabdian kita terhadap tugas profesional kita agar lembaga kita tetap kredibel (cetak miring tambahan penulis).

Kredibilitas Pusat Kurikulum yang selama ini menjadi "rumah produksi kurikulum" (curriculum production house) yang menjadi penopang pengembangan model-model kurikulum, monitoring dan evaluasi pelaksanaan kurikulum, layanan bantuan teknis profesional pengembangan kurikulum mulai dari tingkat pusat sampai tingkat satuan pendidikan, dan pengembangan bahan ajar nyaris kehilangan seluruh kredibilitas lembaganya manakala tidak melakukan pembinaan kepada seluruh staf guna meningkatkan dan mengembangkan kemampuan profesionalnya setiap saat secara dinamis dan terus menerus. Hal itu merupakan sari pati yang setiap saat dikemukakan oleh kepala pusat.

Melalui kegiatan bantuan teknis profesional pengembangan kurikulum kepada TPK provinsi maupun TPK kabupaten/kota dengan pendekatan strategi pemberdayaan ini harapannya ke depan seluruh staf Pusat Kurikulum memiliki profesionalitas yang lebih baik dalam menangani pengembangan kurikulum. Staf profesional merupakan pembantu pimpinan yang melaksanakan tugas bantuan teknis pengembangan kurikulum dengan kemampuan tinggi (profesiens) sebagai sumber kehidupan. Atau dengan kata lain, dengan kegiatan tersebut ditemukan bahwa staf menjadi lebih profesional. Dalam arti menjadi orang yang terdidik dan terlatih dengan baik serta memiliki pengalaman di bidangnya secara handal dan mampu mengelola dirinya sendiri, mengarahkan diri sendiri, mendisiplinkan diri, menjadi matang serta memiliki kesungguhan hati untuk mengerjakan dengan sebaik-baiknya dalam melaksanakan tugasnya sehari-hari.

Selama penulis menjadi salah satu pimpinan di Pusat Kurikulum, melihat dan merasakan bahwa adanya wahana melatih diri untuk berdisiplin dalam cara berfikir dan mengatur pemikiran dengan sistematik serta membangkitkan kompetensi diri merupakan salah satu syarat bagi tim bantuan teknis profesional pengembangan kurikulum di Pusat Kurikulum. Membangkitkan potensi diri untuk berfalsafah meminjam istilah Jelantik (1999) akan memberikan kemudahan dalam menghadapi segala permasalahan, memberi wawasan yang luas dan bekal bagi kehidupan spiritual dan psikologis seseorang. Dengan melakukan pengembangan kemampuan staf sambil memberikan bantuan teknis profesional pengembangan kurikulum ke daerah mengakibatkan staf belajar sambil bekerja sehingga kemampuan terasah dan secara psikologis kemampuan seseorang akan berkembang.

\section{Mengapa perlu memperkuat potensi atau daya (empowering)}

Hasil pengamatan penulis menunjukkan bahwa dengan pemberdayaan staf Pusat Kurikulum terlibat langsung baik sebagai anggota tim, terlebih menjadi penanggung jawab daerah (dalam satu daerah/provinsi/kabupaten/kota umumnya terdiri atas tiga staf teknis) dalam memfasilitasi kegiatan bantuan teknis profesional pengembangan kurikulum kepada TPK daerah ternyata memperkuat potensi atau daya mereka dalam menghadapi komunitas pengembang kurikulum di daerah. Itu berarti bahwa pemberdayaan staf merupakan upaya untuk memandirikan staf, lewat perwujudan potensi kemampuan yang dimiliki staf dirasa cukup berhasil.

Oleh karena itu, pimpinan Pusat Kurikulum menurut hemat penulis selalu mewacanakan bahwa pada setiap upaya pemberdayaan staf harus dipandang sebagai sebuah pemacu untuk menggerakkan kegiatan potensi kompetensi staf. Kerangka pemikiran demikian sejalan dengan fakta yang ditemukan bahwa upaya pemberdayaan staf dapat dilihat dari empat sisi. Pertama, 
pemberdayaan dengan menciptakan suasana atau atau iklim kerja yang memungkinkan potensi staf berkembang. Artinya, setiap staf dapat secara alamiah mengalami menjadi penanggung jawab dan sekaligus menjadi nara sumber pada kegiatan bantuan teknis profesional pengembangan kurikulum kepada TPK daerah sehingga mereka terlatih dan tertantang yang pada gilirannya memiliki potensi yang dapat dikembangkan menuju kehidupan yang lebih baik.

Kedua, pemberdayaan dilakukan di samping untuk memperkuat daya staf sekaligus juga untuk memperkuat kinerja atau daya yang dimiliki Pusat Kurikulum. Dalam rangka memperkuat potensi ini, upaya yang dilakukan Pusat Kurikulum adalah peningkatan taraf profesionalisme, derajat lingkup pengembangan kurikulum, dan akses terhadap sumber-sumber kemajuan ilmu pengetahuan dan teknologi, seni, informasi, lapangan kerja, dan pasar/pengguna.

Ketiga, pemberdayaan melalui pengembangan profesionalitas staf berarti berupaya melindungi untuk mencegah terjadinya persaingan yang tidak seimbang, serta menciptakan kebersamaan dan kemitraan antara yang sudah maju dengan yang belum berkembang, khususnya dalam hal pengembangan kurikulum baik di pusat maupun di daerah. Dengan model semacam inilah proses manusia pembelajar akan berlangsung, di mana kesenjangan antara penerima bantuan teknis dan pemberi yang disebabkan oleh perbedaan latar belakang pekerjaannya bisa dihindari. Dengan demikian, perkembangan pribadi individu tim pengembang kurikulum yang positif bisa dibangun.

Keempat, guna membentuk staf dan komunitas Pusat Kurikulum menjadi lebih mandiri diperlukan wadah pengembangan potensi. Di mana kemandirian tersebut meliputi kemandirian berpikir, bertindak, dan mengendalikan apa yang mereka lakukan tersebut. Kemandirian seluruh staf adalah suatu kondisi yang dialami staf yang ditandai oleh kemampuan untuk memikirkan, memutuskan serta melakukan sesuatu yang dipandang tepat demi mencapai pemecahan masalah-masalah yang dihadapi dengan mempergunakan daya kemampuan yang terdiri kemampuan kognitif, konatif, psikomotorik, afektif, dengan pengerahan sumber daya yang dimiliki oleh lingkungan internal lembaga tersebut.

Keempat aspek tersebut dirasa amat penting bagi Pusat Kurikulum mengingat saat ini harapan sebagian besar para pengelola dan pembina sektor pendidikan banyak tertumpu pada Pusat Kurikulum. Terutama dalam hal pengembangan kurikulum tingkat satuan pendidikan. Hal ini diperkuat, misalnya salah satu rekomendasi dari hasil rapat koordinasi Jaringan Penelitian dan Pengembangan tahun 2010 (situs balitbang, depdiknas) yakni "Perlu dilanjutkan bantuan teknis profesional pengembangan kurikulum kepada seluruh TPK provinsi dan TPK kabupaten/kota oleh Pusat Kurikulum dengan tambahan materi tentang pengembangan budaya dan karakter bangsa, kewirausahaan dan ekonomi kreatif melalui pendekatan pembelajaran siswa aktif".

\section{Mengapa perlu perlindungan (protecting)}

Kegiatan ke daerah untuk bantuan teknis profesioanal pengembangan kurikulum kepada TPK ternyata menjelajah ragam medan yang sangat bervariasi ditinjau dari tingkat kesulitannya. Dalam hal bantuan teknis kepada TPK provinsi, umumnya tidak mengalami hambatan, sebab basis kegiatannya berada di ibu kota provinsi yang secara geografis medannya mudah dijangkau dengan pesawat terbang dari Jakarta. Namun, bila kegiatan tersebut dilakukan terhadap TPK kabupaten/kota, paling tidak ada empat klasifikasi daerah, yaitu medan yang ringan, medan yang berat, medan yang sulit, dan medan yang sangat sulit. Hasil pertemuan bulanan kepada staf, mengemuka, bahwa kabupaten/kota yang didatangi umumnya merupakan daerah antara medan yang berat dan daerah medan yang sulit. Kalaupun pernah ada, paling tidak harus menempuh perjalanan darat rata-rata empat jam dari ibu kota provinsi. Berat dari sisi perjalanan, misalnya lama waktu tempuh, dan sulitnya perjalanan yang harus dilalui untuk mencapai lokasi kegiatan, serta langkanya transportasi umum maupun kondisi jalan yang tidak mulus.

Dengan kondisi jelajah daerah yang begitu rupa, banyak faktor risiko tentunya yang memungkinkan memberikan pengaruh besar secara psikologis terhadap staf. Dari pertemuan rutin bulanan dengan staf, mengemuka, bahwa secara eksternal: kelancaran, keberhasilan, dan 
keselamatan staf dalam melaksanakan bantuan teknis profesioanal pengembangan kurikulum kepada TPK daerah merupakan faktor paling strategis yang membawa pengaruh besar terhadap tata nilai, dan mentalitas seorang staf. Terhadap tingginya risiko yang menghadang di hadapan staf maka maka Kepala Pusat Kurikulum secara serius memikirkan solusi dan mencari alternatif yang paling baik dan layak terjangkau untuk memberikan perlindungan kepada staf. Di samping itu, hal itu juga menyangkut hal tentang bekerja dengan rasa aman, sehingga konsep perlindungan mutlak diperlukan, merujuk pendapatnya Kamerman dan Gabel (2006) sebagai hak bagi semua.

Tentang fenomena medan yang berat tersebut ada pula sebagian staf menganggapnya sebagai hal yang positif karena selama ini daerah itu belum pernah ia kunjungi. Bahkan, sebagian menilai medan yang berat dan medan yang sulit sebagai suatu fragmen yang tidak bisa tidak harus dijalani, dan banyak hal yang menjadi daya dukung akibat adanya proses empati terhadap percepatan informasi kebijakan ke daerah menjadi spiritnya. Dengan adanya orientasi demikian, maka karakter staf sebagai individu dan sebagai komunitas pengembang kurikulum di Pusat Kurikulum dapat terbentuk dan terarahkan sesuai dengan tuntutan ideal bagi proses kegiatan bantuan teknis profesioanal pengembangan kurikulum kepada TPK daerah. Selama mengikuti kegiatan bantuan teknis ke daerah, penulis melihat dan merasakan proses pencapaian lokasi juga dapat menimbulkan pemahaman dari dalam diri atau bathin staf melalui peningkatan kesadaran menuju pikiran super sadar akan tugas dan kewajiban yang akan memunculkan intuisi, kebijaksanaan, dan pemahaman akan kondisi daerah yang difasilitasi.

Tantangan staf dalam menaklukkan medan untuk mencapai kabupaten/kota tertentu, menurut penulis juga berdampak terhadap profesionalitas staf. Dampak terpenting dari proses tersebut di antaranya ialah keterampilan bersosialisasi (social skill) sebagai bagian dari keutuhan potensi staf (pengetahuan, keterampilan, dan sikap). Keterampilan bersosialisasi (social skill) itu sendiri merupakan suatu kemampuan (ability) untuk berinteraksi sesuai dengan konteks sosial budaya yang diwarnai oleh nilai-nilai budaya lokal yang pada hakikatnya akan menjadi perekat kehidupan bersama. Perjalanan ke kabupaten/kota yang akan diberi bantuan teknis umumnya bukan sekadar cuci mata dan membeli cindera mata, tetapi meresapi dan merasakan dinamika kegiatan bantuan teknis pengembangan kurikulum, dan sekaligus merasakan kearifan lokal di sana. Mengingat sebagian besar daerah belum pernah didatangi staf, maka apa yang dibayangkan selama ini tentang daerah itu pada akhirnya bisa dilihat dan dirasakan secara nyata di kota-kota tersebut. Itu sisi-sisi lain yang mengemuka pada saat pertemuan rutin bulanan dengan staf.

Hasil analisis terhadap berbagai kebijakan yang digulirkan pimpinan Pusat Kurikulum (kebetulan penulis dari tahun 2007 hingga awal tahun 2011 menjabat sebagai salah satu kepala bidang) menunjukkan bahwa perlindungan terhadap staf yang melaksanakan kegiatan bantuan teknis profesioanal pengembangan kurikulum kepada TPK daerah merupakan elemen penting dalam strategi kebijakan. Wujud perlindungan yang dilakukan antara lain: 1) setiap staf dimasukkan ke dalam program asuransi dua puluh empat jam, artinya baik pada saat bertugas maupun tidak bertugas keselamatan staf senantiasa dicafer oleh jaminan asuransi; 2) setiap pimpinan wajib memonitor stafnya (lewat telepon atau kirim pesan singkat) manakala mereka sedang bertugas, hal ini dilakukan semata-mata untuk memonitor kondisi, memotivasi, dan mendorong staf mengingat daerah yang dikunjungi secara geografis kadang amat sulit; dan 3) setiap pimpinan wajib mengagendakan forum pertemuan rutin bidang (rata-rata dalam satu bulan dua kali pertemuan) agar ada saling berbagi terhadap dinamika pelaksanakan bantuan teknis profesional pengembangan kurikulum yang baru dilaksanakan.

Bentuk-bentuk perlindungan semacam di atas, menurut hemat penulis, bisa diklasifikasikan ke dalam pembinaan yang bersifat perlindungan sosial. Perlindungan sosial merupakan elemen penting dalam strategi kebijakan di Pusat Kurikulum. Dalam arti yang lebih luas, perlindungan sosial dapat digambarkan sebagai semua inisiatif pimpinan untuk melindungi staf yang 
rentan terhadap risiko karena melaksanakan pekerjaan. Perlindungan sosial mengacu pada proses, kebijakan dan intervensi, yang menanggapi adanya risiko-risiko seperti sakit, cacat, cedera akibat kerja, dan kematian. Kebijakan program perlindungan staf yang diterapkan oleh Pusat Kurikulum yang berupa asuransi dan pertemuan rutin dapat dimasukkan sebagai skema formal, sedangkan skema kebijakan berbasis kepentingan staf (telepon dan kontak dengan cara lain) dapat disebut sebagai jenis perlindungan sosial informal (Suharto, 2006; Suharto 2007).

Dari hasil eksplorasi dengan pola diskusi secara terfokus ditemukan bahwa adanya program perlindungan terhadap staf ternyata mampu memberikan inspirasi yang kuat dalam melandasi kerangka kerja staf untuk melakukan kegiatan bantuan teknis ke daerah. Kerangka kerja ini mulai dari menyusun program kerja, identifikasi materi untuk bantuan teknis, pelaksanaan workshop di daerah, pendampingan penyusunan kurikulum kepada satuan pendidikan sampai penyusunan laporan kegiatan. Ada semacam sugesti bahwa staf terlindungi dan dilindungi. Prinsipnya adalah bahwa bila ada sugesti maka dapat dan pasti mempengaruhi hasil kerja, dan setiap detail perlindungan apa pun memberikan sugesti positif atau negatif. Dan, salah satu teknik yang digunakan pimpinan Pusat Kurikulum untuk memberikan sugesti positif adalah mendudukkan staf secara nyaman, dan meningkatkan partisipasi individu dalam tanggung jawab.

\section{Mengapa perlu memandirikan staf}

Terjadinya keberdayaan sebagaimana diungkap di atas akan memberikan kontribusi pada tercapainya kemandirian staf yang diinginkan. Karena dalam diri staf akan terjadi kecukupan wawasan, yang dilengkapi dengan kecakapan keterampilan, diperkuat oleh rasa memerlukan pengembangan dan perilaku sadar akan kebutuhannya tersebut. Untuk mencapai kemandirian staf diperlukan sebuah proses. Melalui proses belajar maka staf secara bertahap akan memperoleh kemampuan/daya dari waktu ke waktu. Pada gilirannya yang diharapkan dari adanya pemberdayaan adalah untuk mewujudkan potensi/daya yang lebih baik, dan sekaligus juga staf Pusat Kurikulum yang mampu memberikan bantuan teknis profesioanal pengembangan kurikulum di daerah secara ideal serta mandiri.

Hasil diskusi secara terfokus dalam pertemuan rutin bulanan dengan staf yang diselenggarakan di Pusat Kurikulum mengemuka bahwa programprogram bantuan teknis profesional pengembangan kurikulum yang dirancang secara sistematis yang memungkinkan staf menjadi subyek atau pelaku utama bantuan teknis ternyata mampu membentuk kemandirian (selfreliance) staf. Kemandirian dimaksud tidak hanya mencakup pengertian kecukupan diri (selfsufficiency) di bidang pengembangan kurikulum dan layanan bantuan teknis profesioanal pengembangan kurikulum di daerah tetapi juga meliputi faktor staf secara pribadi, yang di dalamnya mengandung unsur penemuan diri (self-discovery) berdasarkan kepercayaan diri (sef-confidence).

Pimpinan Pusat Kurikulum menyadari bahwa inti daripada makna mandiri, yaitu terciptanya kemandirian staf. Sementara untuk mengembangkan kemandirian staf tidak terlepas dari upaya pemberdayaan sumber daya manusia serta potensi staf itu sendiri. Oleh karena itu, kemandirian staf yang berorientasi pada pemenuhan kebutuhan tatanan lembaga yang berbasis pada sumber daya yang tersedia, dan dikelola dengan partisipasi aktif merupakan jawabannya. Sintesis tersebut mengemuka dalam berbagai pertemuan rutin mingguan pimpinan Pusat Kurikulum. Kebijakan itu, menurut hemat penulis, patut disambut baik karena kepala pusat memiliki kehendak baik (good will) memajukan lembaganya. Hal itu juga menunjukkan kepemimpinan Pusat Kurikulum sudah berbeda dengan era kepemimpinan sebelumnya.

Kemandirian staf yang dianut Pusat Kurikulum menurut hemat penulis pada hakikatnya dapat dikelompokkan dalam tiga aspek, yaitu: 1) community oriented, yakni bahwa kegiatan bantuan teknis profesioanal pengembangan kurikulum di daerah didasarkan pada kebutuhan nyata TPK dan disadari daerah setempat; 2) community based, yakni bahwa materi yang disajikan dalam kegiatan bantuan teknis profesioanal pengembangan kurikulum di daerah berdasarkan pada sumber daya TPK setempat, 
sumber daya dinas pendidikan setempat, dan nilai-nilai yang mendukungnya; dan 3) community managed, yakni bahwa kegiatan bantuan teknis profesioanal pengembangan kurikulum di daerah mengikutsertakam stakeholders setempat dari perencanaan, pelaksanaan dan pemetikan hasil kegiatan melalui rapat kerja koordinasi.

Memandirikan staf, bila hal itu dianggap sebagai paham oleh Pusat Kurikulum, menurut penulis merupakan paham yang proaktif dan bukan reaktif atau defensif. Sebab menurut penulis, memandirikan staf merupakan konsep yang dinamis karena mengenali bahwa kehidupan dan kondisi saling ketergantungan senantiasa berubah, baik konstelasinya, perimbangannya, maupun nilai-nilai yang mendasari dan mempengaruhinya. Hal ini diperkuat dari rapat rutin bulanan, yang mengemuka, bahwa dengan dipercaya menjadi penanggung jawab lapangan pada saat kegiatan bantuan teknis profesional pengembangan kurikulum staf menyatakan semakin percaya diri jika disuruh menatar tentang hal yang sama. Hal ini sejalan dengan prinsip belajar yang paling baik adalah belajar dalam konteks.

Salah satu tolok ukur yang dijadikan acuan pimpinan Pusat Kurikulum dalam menilai staf mandiri atau belum mandiri ialah seorang staf dikatakan semakin mandiri apabila kompetensi staf makin meningkat, staf tersebut semakin mampu memfasilitasi dan mengorganisasikan kegiatan bantuan teknis profesioanal pengembangan kurikulum di daerah baik menyangkut penyajian substansi/materi, administrasi maupun pelaporannya. Meningkatnya kompetensi staf, tercermin dari semakin "banyaknya tawaran" kepada staf untuk memfasilitasi daerah dalam hal pendampingan pengembangan kurikulum. Oleh karena itu, agar lembaga Pusat Kurikulum selalu diperhitungkan oleh lembaga/orang lain maka staf harus profesional, maju, dan mandiri.

\section{Simpulan dan Saran Simpulan}

Dari hasil kajian yang telah diuraikan, dan pembahasan singkat di atas dapat disimpulkan bahwa pengembangan kemampuan profesional dalam pengembangan kurikulum sesungguhnya merupakan usaha sadar dan berkesinambungan untuk meningkatkan profesionalisme staf di Pusat Kurikulum. Kajian tentang pemberdayaan staf melalui kegiatan bantuan teknis profesional pengembangan kurikulum kepada TPK daerah mengindikasikan pentingnya menciptakan sebuah budaya lembaga yang sehat secara manajemen, sehingga potensi staf dapat dibangun secara positif dan kondusif yang pada gilirannya bisa berkarya secara mandiri. Secara konseptual proses pengembangan profesionalitas staf di Pusat Kurikulum melalui pemberdayaan, paling tidak ditemukan sekurang-kurangya ada enam rincian kesimpulan.

Pertama, pendekatan pemberdayaan yang diterapkan oleh Kepala Pusat Kurikulum dalam melaksanakan bantuan teknis profesional pengembangan kurikulum kepada TPK daerah dapat dimaknai sebagai: 1) upaya pembinaan, yaitu bahwa staf untuk mencapai keprofesionalitasnya harus dibina karena mereka dalam kondisi perlu peningkatan. Pembinaan menjadikan program pemberdayaan rutin dalam kerangka ada pembina (pimpinan) dan ada yang dibina (staf). Hal ini berimplikasi adanya hubungan patron klien, hubungan atas bawah, hubungan pimpinan dan yang dipimpin; 2) upaya pengembangan, yaitu bahwa kompetensi staf harus senantiasa dikembangkan karena ketertinggalan/ kekurangan dalam kompetensinya. Makna pengembangan menunjukkan bahwa ada power, kemampuan, keahlian yang dimiliki pemrakarsa program dan staf dalam keadaan "kecil" sehingga harus dibesarkan; 3) upaya peningkatan, yaitu bahwa staf harus ditingkatkan profesionalismenya karena dalam kondisi kebutuhan dan kompetisi unit lain serta kompetisi para pengguna hasil lembaga. Karennya, peningkatannya diwarnai oleh ukuranukuran keprofesionalan yang ditentukan oleh pembuat program (services provider); dan 4) "upaya perlindungan", yaitu mengacu pada proses, kebijakan dan intervensi untuk menanggapi kerentanan dan risiko-risiko keamanan seperti sakit, cacat, cedera akibat kerja, dan kematian.

Kedua, kebijakan yang dilakukan oleh Kepala Pusat Kurikulum guna mencapai tujuan dan sasaran lembaga dalam kegiatan bantuan teknis profesional pengembangan kurikulum kepada TPK daerah senantiasa menempuh strategi iklim kerja yang menciptakan: 1) kepercayaan, dengan 
sasaran peningkatan profesionalisme dan kinerja staf dan pelaku organisasi lainnya untuk memberikan peluang kepada mereka, dalam melayani dan mengatasi masalah berkaitan dengan pengembangan kurikulum dan lainnya yang ada di lingkungannya serta merealisasikan aspirasi dan harapan mereka dalam mewujudkan kualitas hidup dan kesejahteraan sosialnya; 2) kemitraan, dengan sasaran menumbuhkembangkan kerja sama, kepedulian, kesetaraan, kebersamaan, kolaborasi dan pelaksanaan jejaring kerja yang menumbuh kembangkan kemanfaatan timbal balik antara pihak-pihak yang bermitra dan mengoptimalkan pelayanan-pelayanan yang bersifat terpadu dalam pengembangan kurikulum; dan 3) partisipasi aktif, dengan sasaran adanya prakarsa, peranan dan keterlibatan semua staf pelaku pengembang kurikulum dan penerima pelayanan, lingkungan penyedia pelayanan dalam pengambilan keputusan, perumusan rencana, pelaksanaan kegiatan dan pemantauan pelaksanaan serta melakukan pilihan terbaik untuk peningkatan pengembangan kurikulumnya.

Ketiga, pemberdayaan staf yang diterapkan di Pusat Kurikulum memiliki tiga karakteristik yang bersifat adaptif, yaitu berbasis staf (staff based), berbasis sumber daya setempat (local resource based) dan berkelanjutan (sustainable). Berbasis staf mengandung makna bahwa staf bertindak sebagai pelaku atau subjek dalam perencanaan dan pelaksanaannya bantuan teknis profesional pengembangan kurikulum kepada TPK daerah. Berbasis sumber daya setempat (local resources based) adalah penciptaan kegiatan yang berbasis sumber daya setempat guna menunjang kegiatan bantuan teknis yang dimaksud. Proses pemberdayaan juga harus dapat berfungsi sebagai penggerak awal (primer mover) dalam peningkatan profesionalisme staf secara berkelanjutan (sustainable).

Keempat, pemberdayaan staf Pusat Kurikulum merupakan upaya untuk membangun daya, dengan cara mendorong, memotivasi, dan membangkitkan kesadaran akan potensi yang dimiliki staf serta berupaya untuk mengembangkannya dengan dilandasi proses kemandirian. Tujuan pemberdayaan staf tersebut adalah untuk membentuk individu staf dan komunitas lembaga menjadi lebih mandiri. Di mana kemandirian tersebut meliputi kemandirian berpikir, bertindak, dan mengendalikan apa yang mereka lakukan dalam lingkup bantuan teknis profesional pengembangan kurikulum kepada TPK daerah.

Kelima, kemandirian staf di Pusat Kurikulum merupakan suatu kondisi yang sangat dibutuhkan yang ditandai oleh kemampuan untuk memikirkan, memutuskan serta melakukan sesuatu yang dipandang tepat demi mencapai pemecahan masalah-masalah yang dihadapi dengan mempergunakan daya kemampuan yang terdiri kemampuan kognitif, konatif, psikomotorik, afektif, dengan pengerahan sumber daya yang dimiliki terhadap nilai-nilai pengembangan kurikulum untuk melaksanakan bantuan teknis profesional pengembangan kurikulum kepada TPK daerah.

Keenam, esensi pemberdayaan yang bertujuan agar staf di kemudian hari mampu memahami dan menjalani kehidupan institusi pengembangan kurikulum secara mendalam, lebih profesional, dapat bekerja secara bermakna, dan dapat turut memuliakan kehidupan dan peran Pusat Kurikulum nampak makin meningkat. Dalam pember-dayaan, staf lebih mampu mengenali kebutuhan-kebutuhannya, merumuskan rencanarencananya, dan melaksanakan kegiatan bantuan teknis profesional pengembangan kurikulum kepada TPK daerah serta permasalahanya. Dengan kata lain, pendekatan pemberdayaan staf merupakan konsep peningkatan kapasitas staf "dari, oleh, dan untuk" staf.

Dalam jiwa pemberdayaan tersebut juga sekaligus tertanam semangat solidaritas sosial, yaitu hubungan sosial yang selalu didasarkan pada perasaan moral bersama, kepercayaan bersama, dan tujuan bersama. Di samping itu, sebagai pejabat funsional peneliti maupun perekayasa pendidikan (sebagian besar staf menjadi perekayasa atau peneliti) merujuk sintesis Somantrie (situs Puskur.net, 3/3/2011) staf Pusat Kurikulum dalam melaksanakan tugas profesionalnya hendaknya selalu menggunakan prinsip: 1) start with the experience; 2) identify common knowledge, attitudes, and skills; 3) introduce new skills, information, and ideas to be learned; 4) practice skills and integrate new information and ideas; 5) evaluate and reflect; dan 6) apply new skills, attitudes, and knowledge in new situations or in action for change. 
Sutjipto, Bantuan Teknis Profesional Pengembangan Kurikulum Kepada Tim Pengembang Kurikulum Daerah Sebagai Wahana Pemberdayaan.....

\section{Saran}

Saran yang dikemukakan berkaitan dengan pemberdayaan staf dalam memfasilitasi kegiatan bantuan teknis profesional pengembang-an kurikulum kepada TPK daerah sebagai berikut. Pertama, Kepala Pusat Kurikulum, (saat ini telah menjadi Pusat Kurikulum dan Perbukuan) hendaknya selalu membuat kebijakan yang berujud program tahunan berkait dengan kegiatan bantuan teknis profesional pengembangan kurikulum kepada TPK daerah secara terus menerus dan berkelanjutan. Di samping itu, kepala pusat hendaknya juga membuat kebijakan yang menumbuhkembangkan minat dan motivasi (motivator) staf untuk meningkatkan kapasitasnya dengan mendorong strategi pemberdayaan secara berkelanjutan pula. Mengingat bahwa pemberdayaan staf yang dilakukan selama ini terbukti cukup efektif guna meningkatkan profesiolaisme staf dalam memfasilitasi kegiatan bantuan teknis profesional pengembangan kurikulum kepada TPK daerah. Ajang itu terbukti pula dapat dijadikan berkembangnya potensi staf secara mandiri, mampu mengkreasi (kreator) berbagai cara, dan kemauan mencoba melakukan pembaharuan-pembaharuan dalam bantuan teknis pengembangan kurikulum sebagai tuntutan profesi (inovator). Partisipasi aktif staf secara mandiri dalam melaksanakan kegiatan tersebut harus selalu ditumbuhkan, didorong dan dikembangkan secara bertahap, ajeg, dan berkelanjutan.

Kedua, dalam menghadapi pelaksanaan kegiatan bantuan teknis profesional pengembangan kurikulum kepada TPK daerah para pimpinan di Pusat Kurikulum dan Perbukuan hendaknya dapat meningkatkan peran yang cukup signifikan guna mendorong peningkatan profesionalitas staf yang mengarah pada peningkatan kompetensi agar lebih bermakna, efisien, dan efektif dalam melaksanakan kegiatan. Dengan pemberian peran dan tanggung jawab seperti itu, akan terbentuk pemberdayaan yang mampu melatihkan serangkaian kemampuan serta sikap dan nilai penting kepada staf agar: 1) menghayati proses bantuan teknis profesional pengembangan kurikulum dengan melakukan sesuatu yang bermakna (learning to do), suatu proses kegiatan secara aktif; dan 2) proses bantuan teknis profesional pengembangan kurikulum dapat memungkinkan lahirnya staf yang mandiri (learning to be). Dengan adanya pemberdayaan, penekanan kegiatan bantuan teknis profesional pengembangan kurikulum kepada TPK daerah bukanlah apa yang harus mereka berikan (learning what to be learn), tetapi belajar bagaimana belajar memberi (learning how to learn).

Ketiga, kegiatan bantuan teknis profesional pengembangan kurikulum kepada TPK daerah spektrumnya cukup luas, dan ruang lingkupnya dapat meliputi semua aspek kepentingan pengembangan, pelaksanaan, dan evaluasi kurikulum. Kepada seluruh staf hendaknya memanfaatkan secara baik momentum tersebut guna dijadikan tata kelola peningkatan profesionalismenya dalam memfasilitasi kegiatan serupa ke depan, sehingga dapat dijadikan suatu pengalaman dan kebiasaan jika ia menatar hal yang sama. Dengan demikian, mengolah balikan pengalaman secara efektif dan kreatif dalam kegiatan bantuan teknis profesional pengembangan kurikulum kepada TPK daerah senantiasa dijadikan sebagai upaya meningkatkan kemampuannya, dapat memilih cara yang efisien, dapat menggunakan strategi yang bervariasi, dan yang dilakukan dengan penuh kesadaran.

Keempat, untuk menunjang segala keperluan yang dikehendaki dalam kegiatan bantuan teknis profesional pengembangan kurikulum kepada TPK daerah, di samping staf harus prima dan profesional dalam memfasilitasi "pasar/ konsumen", lembaga juga harus efektif, efisien, dan proaktif dalam memanfaatkan segala sumber daya baik yang ada di pusat maupun di daerah untuk digandeng sebagai mitra kerja. Guna kesemuanya itu, maka salah satu hal yang perlu dilakukan adalah peningkatan kapasitas lembaga dan pemasyarakatan pembentukan tim pengembang kurikulum di semua lini di daerah. Hal ini dilakukan agar daerah memahami betul makna kebijakan berkait dengan pengembangan kurikulum tingkat satuan pendidikan. Jika ini semua dilakukan secara terus menerus dampak manfaat peningkatan profesional staf di Pusat Kurikulum dan Perbukuan akan lebih dasyat daripada hanya sekadar melaksanakan program dan mempertanggungjawabkan kegiatan. 


\section{Pustaka Acuan}

Abeng, Tantri. 1997. Dari Meja Tantri Abeng, Gagasan, Wawasan, Terapan dan Renungan. Jakarta:

Pustaka Sinar Harapan. hal. 3.

Adimihardja, Kusnaka dan Hikmat, Harry. 2000. PRA: Participatory Research Appraisal dalam Pelaksanaan Pengabdian Kepada Masyarakat. Bandung: Humaniora Utama Press.

Buchori, Mochtar. Pedagogik Kritis. Kompas, Senin 21 Maret 2011.

Bryant \& White. 1987. http://www.pemberdayaan.com/pemberdayaan/konsep-pemberdayaanmembantu-masyarakat-agar-bisa-menolong-diri-sendiri.html. Diunduh 27 Februari 2011.

Craig, G \& M. Mayo. 1995. Community Participation and Empowerment: The Human face of Structural Adjustment or Tools for Demoratic Transformation in Craig, G \& Mayo, M (ed.) 1995. Community Empowerment: A Reader in Participation and Development. London : Zed Books.

Crowl, T. K. 1996. Fundamentals of Educational Rearch. Chicago: Brown \& Benchmark.Horn dkk., 1973. The advanced Learner's Dictionary of Current English. Great Britain: Oxford University. hal. 733.

Departemen Pendidikan Nasional. 2003. Undang-Undang Republik Indonesia Nomor 20 Tahun 2003 tentang Sistem Pendidikan Nasional. Jakarta.

Fairclough, Nourman. 1997. Critical Discourse Analisis: The Crutical Study of Language. London-New York: Longman.

Hikmat, Harry. 2001. Strategi Pemberdayaan Masyarakat. Bandung : Humaniora Utama Press.

Hornby, A. S., A. P. Cowie and A. C. Gimson. 1973. The advanced Learner's Dictionary of Current English. Great Britain: Oxford University. hal. 733.

http://www.puskur.net/index.php?option=com content\&view=article\&id =77: banprofhermana\&catid=51: opini\&Itemid=71, diunduh Kamis, 3 Maret 2011 pukul 13.20.

Jelantik, AAM. 1999.Estetika: Sebuah Pengantar. Masyarakat Seni Pertunjukan Indonesia, Bandung.

Kamerman, Sheila B. and Shirley Gatenio Gabel. 2006. "Social Protection for Children and their Families:

A Global Overview," paper presented at the conference on Social Protection Initiatives for Children, Women, and Families: An Analysis of Recent Experience, sponsored by UNICEF and the Graduate Program in International Affairs at the New School, October 30 and 31.

MacArdle, J. 1989. Community Development Tools of Trade. Community Quartely Journal. Vol 16.

Prijono, Onny S. dan Pranarka, A.M.W. 1996. Pemberdayaan : konsep, kebijakan, dan implementasi. Jakarta : Centre for Strategic and International Studies.

Pusat Bahasa, Departemen Pendidikan Nasional. 2001. Kamus Besar Bahasa Indonesia, Jakarta: Balai Pustaka. Edisi III, hal. 897.

Sax, G. 1979. Foundations of Educational Research. New Jersey: Prentice-Hall, Inc.

Simon, B.L. 1990. Rethinking Empowerment. Journal of Progressive Human Services, 1. 27-39.

Somantrie, Hermana: http://www.puskur.net/index.php?option=com_content\&view=article\&id=77: banprof-hermana\&catid=51: opini\&Itemid=71, diunduh Kamis, 3 Maret 2011 pukul 13.20.

Sudjana, Nana \& Ibrahim. 1989. Penelitian \& Penilaian Pendidikan. Bandung: Sinar Baru.

Suharto, Edi. 2006. Membangun Masyarakat memberdayakan Rakyat: Kajian Strategis Pembangunan Kesejahteraan Sosial dan Pekerjaan Sosial. Bandung: Refika Aditama.

Suharto, Edi. 2007. Kebijakan Sosial sebagai Kebijakan Publik, Peran Pembangunan Kesejahteraan Sosial dan Pekerjaan Sosial dalam Mewujudkan Negara Kesejahteraan di Indonesia. Bandung: Alfabeta.

Sulistiyani, Ambar Teguh. 2004. Kemitraan dan Model-model Pemberdayaan. Yogyakarta: Gava Media. Trianto dan Tuti, Titik Triwulan. 2006. Tinjauan Yuridis Hak Serta Kewajiban Pendidik. Jakarta: Prestasi Pusaka. 